CZASOPISMO INŻYNIERII LĄDOWEJ, ŚRODOWISKA I ARCHITEKTURY JOURNAL OF CIVIL ENGINEERING, ENVIRONMENT AND ARCHITECTURE

JCEEA, t. XXXIV, z. 64 (1/17), styczeń-marzec 2017, s. 43-51, DOI:10.7862/rb.2017.5

\author{
Anna ŚPIEWAK ${ }^{1}$ \\ Małgorzata ULEWICZ ${ }^{2}$
}

\title{
ANALIZA TRWALOŚCI STALOWYCH OBIEKTÓW MOSTOWYCH W ZALEŻNOŚCI OD ŚRODOWISKA KOROZYJNEGO
}

\begin{abstract}
W artykule przedstawiono aktualne statystyki dotyczące sieci dróg województwa śląskiego zarządzanych przez Zarząd Dróg Wojewódzkich oraz ilości konstrukcji w zależności od typu ich ustroju nośnego. Poruszono aktualny w Polsce problem dotycząc trwałości stalowych obiektów mostowych z uwzględnieniem zjawiska korozji. Scharakteryzowano podstawowe czynniki wpływające na szybkość korozji niezbędne do oszacowania wpływu korozji na trwałość stalowych mostów drogowych m.in. czynniki atmosferyczne oraz czynniki wynikające z utrzymania obiektu. Zwrócono szczególną uwagę na kategorie korozyjności środowiska w którym wznoszone są konstrukcje stalowe, mające bardzo znaczący wpływ na postęp i szybkość procesu korozji. Omówiono procedurę badania wpływu korozji na trwałość stalowych konstrukcji mostowych opracowaną przez Instytut Badawczy Dróg i Mostów. Przedstawiono metodę obliczania czasu bezawaryjnego użytkowania konstrukcji. Szczegółowo scharakteryzowano, niezbędne do przeprowadzenia procedury obliczeniowej, redukcyjne współczynniki trwałości. Na podstawie własnej analizy określono czas bezawaryjnej pracy wybranych konstrukcji. Do obliczeń przyjęto cztery rzeczywiste mosty o dźwigarach stalowych, będących konstrukcją nośną dla żelbetowej płyty pomostowej. Wybrane mosty wzniesione zostały w różnych częściach kraju, charakteryzujących się odmienną agresywnością środowiska - środowisko nadmorskie, górskie, miejskie oraz neutralne. Obiekty różnią się rodzajem korozji występującym na ustrojach nośnych konstrukcji. Mosty różnią się również czasem powstania obiektów, co wpływa w znacznym stopniu na ich bezpieczne użytkowanie. Na zakończenie przeanalizowano wyniki otrzymane z przeprowadzonej analizy.
\end{abstract}

Słowa kluczowe: stalowe obiekty mostowe, trwałość konstrukcji, korozja

1 Autor do korespondencji / corresponding author: Anna Śpiewak, Politechnika Częstochowska, Wydział Budownictwa, ul. Akademicka 3, 42-200 Częstochowa; tel. 343250 942; aspiewak@bud.pcz.czest.pl

2 Małgorzata Ulewicz, Politechnika Częstochowska, Wydział Budownictwa, ul. Akademicka 3, 42-200 Częstochowa; tel. 34 3250 935; ulewicz@ bud.pcz.czest.pl 


\section{Wprowadzenie}

Sieć dróg województwa śląskiego to $1218,6 \mathrm{~km}$ dróg w ciągu których znajduje się 316 obiektów mostowych o całkowitej długości $6838 \mathrm{~m}$. Miejskich obiektów mostowych o konstrukcji stalowej jest 16, a 14 to obiekty zlokalizowane na terenach pozamiejskich, co stanowi 9,49\% wszystkich mostów drogowych (rys 1.) zarządzanych przez Zarząd Dróg Wojewódzkich (ZDW) w Katowicach [1]. Większość stalowych obiektów mostowych to konstrukcje stare, narażone w znacznym stopniu na korozję. Do powstawania ognisk korozyjnych może doprowadzić nieodpowiednie utrzymanie, modernizacja oraz niewłaściwa eksploatacja, a wynikiem korozji jest obniżenie trwałość stalowych obiektów mostowych. Nieodzownym elementem jest zatem zapobieganie korozji w taki sposób, aby ograniczyć długotrwałe prace remontowe lub całkowite wyłączenie obiektu mostowego z eksploatacji.

\section{Obiekty mostowe zarządzane przez ZDW w Katowicach}

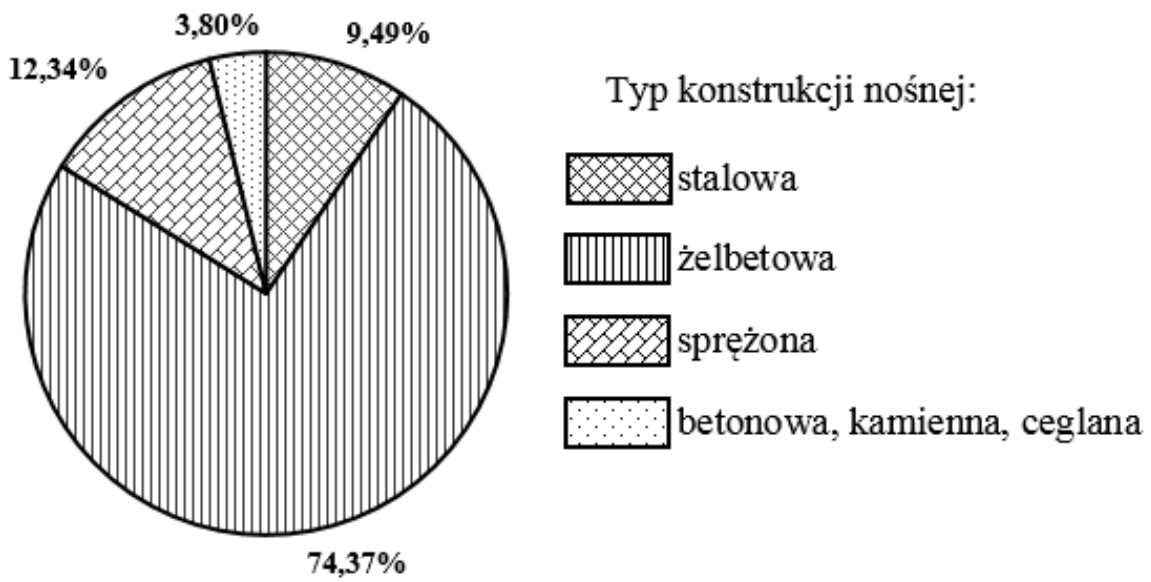

Rys. 1. Obiekty mostowe w zależności od typu konstrukcji nośnej w województwie śląskim, oprac. własne wg [1]

Fig. 1. The bridges depending on the type of load-bearing structure in the Silesian province, own elaboration by [1]

\section{Metodologia określania trwałości konstrukcji stalowych drogowych obiektów mostowych z uwzględnieniem korozji}

Problem trwałości konstrukcji stalowych jest tematem bardzo aktualnym, ponieważ obniżona trwałość konstrukcji powoduje konieczność naprawy lub wymianę elementów, co wiąże się ze zużyciem materiałów i energii oraz emisją zanieczyszczeń. Trwałość konstrukcji zapewnia się przez odpowiednie jej zaprojektowanie, wykonanie, zabezpieczenie oraz utrzymanie w zaprojektowanym 
okresie użytkowania, który zgodnie z wymogami norm europejskich wynosi 100 lat. Do obliczeń przyjmuje się czas pracy mostu, ale nie można zapomnieć o odpowiednim utrzymywaniu i konserwacji obiektu $[2,3]$.

Stal to materiał o jednorodnej strukturze, charakteryzujący się dużym współczynnikiem sprężystości, dzięki temu jest to materiał doskonale odpowiadający założeniom metod obliczeniowych. Właściwości mechanicznie stali wpływają na bezpieczeństwo pracy konstrukcji stalowych, jednak zjawiskiem destrukcyjnym, wpływającym niekorzystnie na wytrzymałość i trwałość stali jest jej korozja, polegająca na utlenianiu się metalu. Należy podkreślić, że obiekty mostowe o nośnym ustroju dźwigarów pełnych lub kratowych ulegają znacznym uszkodzeniom w wyniku korozji atmosferycznej. Najważniejsze czynniki wpływające na szybkość korozji stali to stężenie zanieczyszczeń powietrza, które reagują ze stalą konstrukcyjną, wilgotność względna powietrza oraz temperatura na powierzchni elementu, która może być wyższa lub niższa od temperatury punktu rosy wpływającej na kondensację powierzchniową. Dlatego tak istotnym aspektem $\mathrm{w}$ procesie projektowania konstrukcji jest uwzględnienie klasy agresywności środowiska, w którym konstrukcja będzie zlokalizowana. Klasy agresywności środowiska oraz kategorie korozyjności wraz z przykładami typowych środowisk dla klimatu umiarkowanego zostały zdefiniowane w normie PN-EN ISO 12944-2:2001: Farby i lakiery - Ochrona przed korozją konstrukcji stalowych za pomocą ochronnych systemów malarskich - Część 2: Klasyfikacja środowisk [4]. Szybkość korozji zależy także od ogólnych warunków atmosferycznych (warunki wiejskie, miejskie, morskie i przemysłowe) w miejscu, w którym zlokalizowany jest obiekt.

Oszacowanie wpływu korozji na trwałość obiektów mostowych jest złożoną procedurą, która wymaga przede wszystkim określenia rodzaju korozji oraz wielkości wżerów korozyjnych w konstrukcji. Istotne jest również określenie miejsc występowania korozji na powierzchniach nośnych elementów stalowych, ponieważ nierównomierny rozkład produktów korozji oraz związane z nim ubytki stali konstrukcyjnej w przekrojach elementów nośnych powodują koncentrację naprężeń. Zjawisko korozji i równoczesne cyklicznie zmieniające się naprężenia powodują znacznie większy spadek nośności konstrukcji, niż działania każdego czynnika osobno. Zmienne naprężenia intensyfikują korozję, a korozja przyspiesza rozwój procesu zmęczenia materiału konstrukcyjnego.

Na etapie użytkowania stalowych obiektów mostowych może dojść do pęknięcia konstrukcji, które poddawane są w trakcie użytkowania wielu okresowo zmiennym obciążeniom. Koncentracja naprężeń wpływa na zmęczenie materiału, co prowadzi w konsekwencji do zniszczenia zmęczeniowego elementów konstrukcji. Metoda szacowania wpływu korozji na trwałość konstrukcji stalowych obiektów mostowych polega na analizie sprzężonego i integralnego układ materiał - środowisko, gdzie materiał musi charakteryzować się wysoką odpornością i wytrzymałością, a środowisko to czynnik niszczący, agresywny i destrukcyjnie wpływający na materiał [5-10]. 


\section{Procedura badania wpływu korozji na trwałość stalowych konstrukcji mostowych - charakterystyka parametrów i współczynników redukcyjnych}

Metoda szacowania wpływu korozji na trwałość obiektów mostowych o stalowej konstrukcji nośnej została opracowana w oparciu o badania prowadzone przez Instytut Badawczy Dróg i Mostów. Wykorzystywane w procedurze obliczeniowej zmniejszające, korekcyjne współczynniki trwałości (tab. 1) oraz

Tabela 1. Redukcyjne współczynniki trwałości, oprac. własne wg [5]

Table 1. Reduction coefficient of durability, own elaboration by [5]

\begin{tabular}{|c|c|c|}
\hline \multicolumn{3}{|c|}{ Współczynnik $S_{A}$ zależny od stopnia agresywności środowiska } \\
\hline $\begin{array}{c}\text { Kategoria } \\
\text { korozyjności }\end{array}$ & Przykład typowych środowisk zewnętrznych & Wartość \\
\hline $\begin{array}{c}\mathrm{Cl} \\
\text { Bardzo mała }\end{array}$ & $\begin{array}{l}\text { atmosfery w małym stopniu zanieczyszczone, głównie obsza- } \\
\text { ry wiejskie }\end{array}$ & 0,99 \\
\hline $\begin{array}{c}\mathrm{C} 2 \\
\mathrm{Mała}\end{array}$ & $\begin{array}{l}\text { atmosfery miejskie i przemysłowe, umiarkowanie zanie- } \\
\text { czyszczone; tereny przybrzeżne o niewielkim zasoleniu }\end{array}$ & 0,98 \\
\hline $\begin{array}{cl}\mathrm{C} 3 \\
\text { Średnia }\end{array}$ & tereny przemysłowe i nadbrzeżne o średnim zasoleniu & 0,97 \\
\hline $\begin{array}{c}\text { C4 } \\
\text { Duża }\end{array}$ & $\begin{array}{c}\text { tereny przemysłowe o dużej wilgotności powietrza } \\
\text { i agresywnej atmosferze }\end{array}$ & 0,96 \\
\hline $\begin{array}{l}\text { C5-I } \\
\text { Bardzo duża } \\
\text { (przemysłowa) }\end{array}$ & $\begin{array}{c}\text { tereny przemysłowe o dużej wilgotności powietrza } \\
\text { i agresywnej atmosferze }\end{array}$ & \multirow{2}{*}{0,95} \\
\hline $\begin{array}{l}\text { C5-M } \\
\text { Bardzo duża } \\
\text { (morska) }\end{array}$ & $\begin{array}{l}\text { tereny nadmorskie o dużym zasoleniu oraz obszary oddalone } \\
\text { od brzegu w głąb morza atmosfera }\end{array}$ & \\
\hline \multicolumn{3}{|c|}{ Współczynnik $K_{R}$ zależy od rodzaju korozji } \\
\hline & Rodzaj korozji & Wartość \\
\hline & korozja nierównomierna, korozja wżerowa & $\begin{array}{l}\text { wartość wg wzoru (1) } \\
\text { i (2) }\end{array}$ \\
\hline & korozja równomierna & 0,97 \\
\hline korozja podpow & $\begin{array}{l}\text { okowa, korozja szczelinowa, korozja przyspoinowa, korozja } \\
\text { galwaniczna }\end{array}$ & 0,99 \\
\hline \multicolumn{3}{|c|}{ Współczynnik $T_{W}, T_{i}, T_{D}$ zależne od oceny stanu technicznego } \\
\hline & Ocena stanu technicznego & Wartość \\
\hline & 0 & 0,90 \\
\hline & 1 & 0,94 \\
\hline & 2 & 0,96 \\
\hline & 3 & 0,98 \\
\hline & 4 & 0,99 \\
\hline & 5 & 1,00 \\
\hline \multicolumn{3}{|c|}{$\begin{array}{l}T_{W} \text { - współczynnik zależny od stanu technicznego systemu odwodnienia, } \\
T i \text { - współczynnik zależny od stanu technicznego izolacji, } \\
T_{D} \text { - współczynnik zależny od stanu technicznego urządzeń dylatacyjnych. }\end{array}$} \\
\hline \multicolumn{3}{|c|}{ Współczynnik $\beta$ zależny od klasy drogi } \\
\hline & Klasa drogi & Wartość \\
\hline & Dla drogi klasy A & 0,90 \\
\hline & Dla drogi klasy $\mathrm{S}$ & 0,93 \\
\hline & Dla drogi klasy GP & 0,95 \\
\hline & Dla drogi klasy $\mathrm{G}$ & 0,96 \\
\hline & Dla drogi klasy Z, L, D & 0,99 \\
\hline
\end{tabular}


zależności matematyczne umożliwiające wyznaczenie czasu eksploatacji obiektu skorodowanego, zostały przyjęte na podstawie analizy przeprowadzonych badań. Oszacowanie wpływu korozji na trwałość jest możliwe jedynie po określeniu stopnia agresywności środowiska, w którym zlokalizowano obiekt i rodzaju korozji występującej w ustroju nośnym, stanu technicznego urządzeń odwadniających, dylatacyjnych oraz izolacji. Istotne jest również ustalenie klasy drogi na podstawie rodzaju ruchu oraz wieku analizowanego obiektu mostowego. Przedstawiona metoda, jest sposobem na określenie okresu bezpiecznej, bezawaryjnej pracy konstrukcji, w którym zjawisko korozji postępuje z dużym prawdopodobieństwem (około $90 \%)$ [5, 6].

Wartość współczynnika $K_{R}$ należy przyjąć jako średnią arytmetyczną wartości parametru skorodowania i- ego dźwigara mostowego $\mathrm{w}_{\mathrm{i}}$, który oblicza się względem włókien górnych i dolnych przekroju ze wzorów (1) i (2) [5]:

$$
\begin{aligned}
& w_{i d_{1}}=\frac{W_{i d_{-} k o r}}{W_{i d_{-} n o m}} \\
& w_{i g}=\frac{W_{i g_{-} k o r}}{W_{\text {gd_nom }}}
\end{aligned}
$$

gdzie: $w_{i d}, w_{i g}$ - parametr korozyjny dźwigara i,

$W_{i d \_k o r}, W_{i g \_k}$ - wskaźnik wytrzymałości przekroju na zginanie skorodowanego dźwigara i, względem włókien dolnych i górnych, $\left[\mathrm{cm}^{3}\right]$,

$W_{i d \_n o m}, W_{i g \_n o m}-$ wskaźnik wytrzymałości przekroju na zginanie nieskorodowanego dźwigara i, względem włókien dolnych i górnych, $\left[\mathrm{cm}^{3}\right]$ ).

Scharakteryzowane redukcyjne, współczynniki trwałości konstrukcji pozwalają na wyznaczenie czasu eksploatacji obiektu mostowego podczas którego proces korozji cały czas postępuje. Etapem pośrednim wyznaczenia wpływu korozji na trwałość stalowych mostów drogowych jest określenie stopnia skrócenia czasu bezawaryjnej pracy konstrukcji [5]:

$$
S_{T}=K_{R} \cdot S_{A} \cdot \frac{T_{W}+T_{i}+T_{D}}{3}
$$

gdzie: $S_{T}$ - stopień skrócenia czasu bezawaryjnej pracy konstrukcji,

$K_{R}, S_{A}, T_{W}, T_{i}, T_{D}$ - współczynniki zmniejszające wg tab. 1.

Końcowym efektem obliczeń jest uzyskanie czasu bezawaryjnej i bezpiecznej pracy konstrukcji stalowego obiektu mostowego $T_{e} \mathrm{z}$ uwzględnieniem wieku obiektu [5].

$$
T_{e}=T_{m} \cdot S_{T} \cdot \beta-W
$$


gdzie: $T_{e}$ - projektowany czas bezawaryjnej pracy konstrukcji pod wpływem korozji (w latach),

$T_{m}$ - projektowany czas eksploatacji obiektu (w latach),

$S_{T}$ - stopień skrócenia czasu bezawaryjnej pracy konstrukcji,

$\beta$ - współczynnik zmniejszający wg tab. 1 ,

$W$ - wiek mostu (w latach).

\section{Analiza trwałości rzeczywistych konstrukcji w zależności od lokalizacji i środowiska}

Zgodnie z procedurą szacowania trwałości stalowych obiektów mostowych uwzględniającą postęp zjawiska korozji przeanalizowano cztery wybrane obiekty rzeczywiste. Dwa obiekty to mosty wybudowane na terenie województwa śląskiego w Wiśle Malinka i Nędzy, zlokalizowane w ciągu dróg wojewódzkich odpowiednio nr 942 i 922 zarządzanych przez ZDW. Dla porównania wybrano dodatkowo dwa obiekty zróżnicowane pod względem środowiska - most drogowy w Łebie zlokalizowany w ciągu drogi 104039 G zarządzanej przez gminę miasta Łeba oraz most drogowy będący w ciągu drogi powiatowej 1661D we Wrocławiu. Analizę przeprowadzono w oparciu o dane z raportów dotyczących przeglądów szczegółowych wybranych obiektów mostowych. Na podstawie danych sporządzono tabelę 2, ze współczynnikami trwałości dla analizowanych obiektów oraz wyznaczono stopień skrócenia czasu bezawaryjnej pracy konstrukcji mostów drogowych oraz całkowity czas bezawaryjnej pracy konstrukcji. Brak dokumentacji projektowej wszystkich czterech obiektów mostowych spowodowało przyjęcie do dalszej analizy projektowany okres użytkowania obiektów 100 lat, który został ustalony na podstawie doświadczenia pracowników ZDW w Katowicach oraz w oparciu o wytyczne z działu V Rozporządzenia Ministra Transportu i Gospodarki Morskiej w sprawie warunków technicznych, jakim powinny odpowiadać drogowe obiekty inżynierskie i ich usytuowanie.

Przeprowadzona analiza wykazała, że największy wpływ na stopień skrócenia czasu bezawaryjnej pracy konstrukcji mostów drogowych ma zmniejszający współczynnik zależny od rodzaju korozji. Istotna również jest klasa agresywności środowiska, ponieważ zanieczyszczenia powietrza oraz jego zasolenie, przyspiesza postęp zjawiska korozji, co widać w przypadku mostu w Łebie. Natomiast z klasą drogi wiąże się Zimowe Utrzymanie Drogi, a tym samym ilość oraz stężenie środków zapobiegających powstaniu - oblodzenia, gołoledzi, śliskości pośniegowej oraz pozostałości świeżego śniegu w okresach zimowych, które również przyczyniają się do korozji dźwigarów mostowych. Analizowane mosty to obiekty o niskich klasach dróg G lub L, jednak w dwóch ostatnich przypadkach (most we Wrocławiu oraz Łebie) są to mosty będące w ciągu głównych arterii miasta, których utrzymane w okresie zimowym, jest kluczowe dla infrastruktury miasta. Obiekt zlokalizowany w Wiśle w ciągu drogi wojewódz- 
Tabela 2. Dane dotyczące analizowanych rzeczywistych obiektów mostowych [oprac. własne]

Table 2. Data on the analyzed bridges of real [own elaboration]

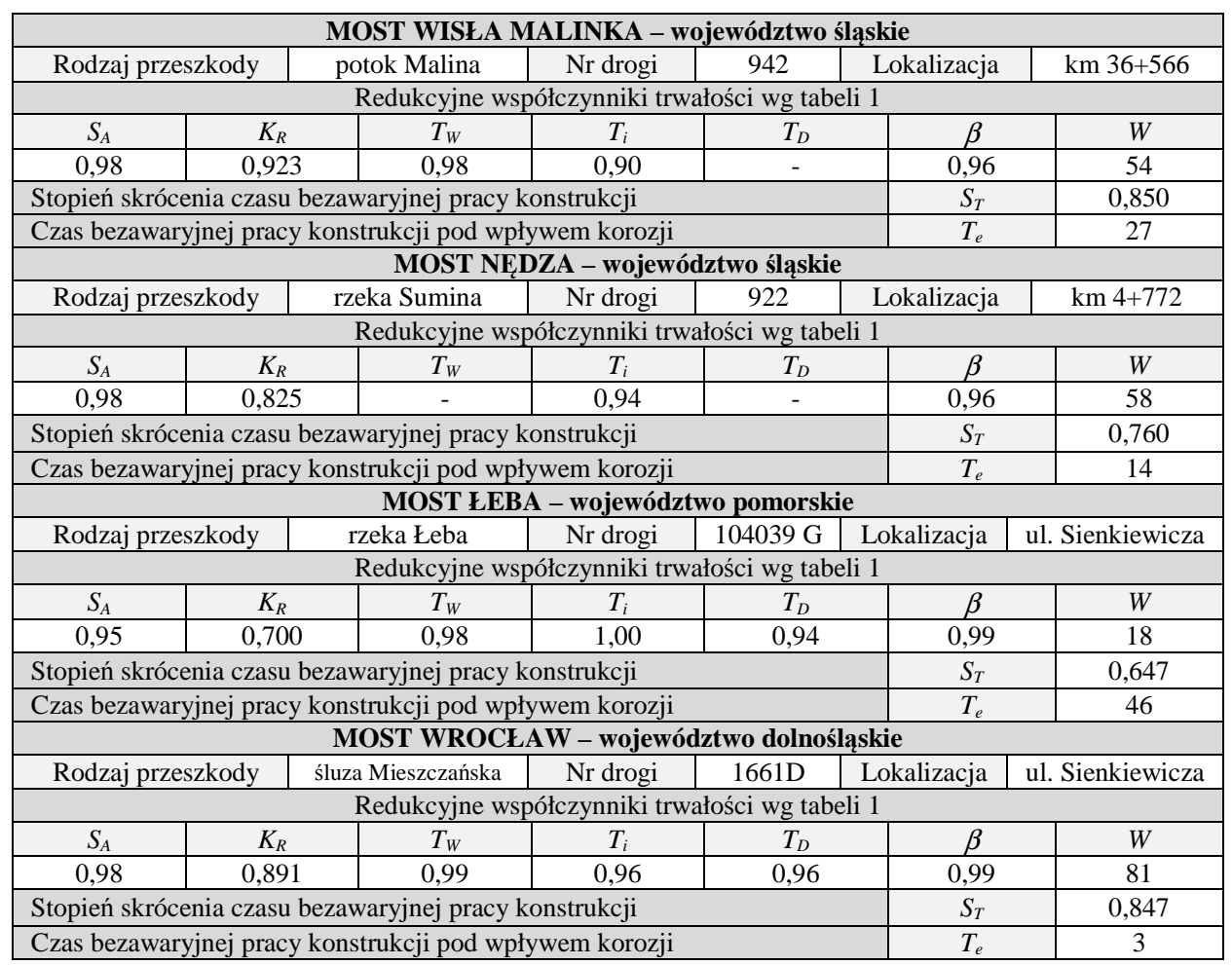

kiej 942 prowadzącej z Wisły do Szczyrku przez przełęcz Salmopolską charakteryzującą się ostrym kontem nachylania oraz kilkunastoma ostrymi zakrętami, wymaga ze względów bezpieczeństwa użytkowników drogi idealnego zimowego utrzymanie. Warto również zwrócić uwagę, że stan techniczny elementów analizowanych konstrukcji jest najczęściej niepokojący lub niedostateczny, a ostateczna ocena stanu technicznego całych obiektów wynosi 2-3. Bardzo często po przeglądach stwierdza się, że istniejące uszkodzenia mogą stanowić zagrożenie bezpieczeństwa ruchu publicznego lub mogą ograniczyć przydatność obiektu mostowego do użytkowania. Dlatego tak istotna jest konserwacja, renowacja i modernizacja obiektów oraz ich zabezpieczeń antykorozyjnych.

\section{Wnioski}

Przedstawiona metoda szacowania czasu bezawaryjnej pracy konstrukcji $\mathrm{z}$ uwzględnieniem korozji jest uzasadniona, a wyniki otrzymane $\mathrm{z}$ analizy niosą istotne informacje o obiekcie mostowym o stalowej konstrukcji nośnej pomocne w przypadku sporządzania raportów z okresowych przeglądów stanu technicz- 
nego mostów i wiaduktów. Bezawaryjny czas pracy mostu wyznaczany jest jednak w określonym wieku eksploatowanej konstrukcji, dlatego wydaje się istotnym z uwagi na ciągłość procesu korozji oszacowanie tempa postępowania tego destrukcyjnego zjawiska. Oszacowanie postępu korozji uwzględniając warunki środowiskowe i eksploatacyjne jest istotne w związku z planowanymi pracami modernizacyjnymi i remontowymi. Dlatego, metoda szacowania wpływu korozji na trwałość konstrukcji stalowych drogowych obiektów mostowych jest odpowiednia dla wstępnej szacunkowej analizy konstrukcji, jednak do całkowitego określenia nośności i trwałości z uwzględnieniem zmęczenia materiału oraz szybkości rozwoju korozji stalowych obiektów mostowych niezbędne jest przeprowadzenie dodatkowych obliczeń, co stanowi cel dalszej pracy.

Podziękowanie. Badania finansowane z Grantu SK-PL-2015-0004

\section{Literatura}

[1] Informacje udostępnione przez Zarząd Dróg Wojewódzkich w Katowicach.

[2] PN-EN 1993-2:2010 Eurokod 3. Projektowanie konstrukcji stalowych. Część 2: Mosty stalowe.

[3] Rozporządzenia Ministra Transportu i Gospodarki Morskiej w sprawie warunków technicznych, jakim powinny odpowiadać drogowe obiekty inżynierskie i ich usytuowanie, działu V. Trwałość obiektów inżynierskich, § 153. Okres użytkowania obiektów inżynierskich.

[4] http://budownictwopolskie.pl/artykul/charakterystyka_stali_i_konstrukcji_stalowych \{dostęp 28.04.2016 r.\}.

[5] Czerepak A., Czudek H., Pryga A., Wysokowski A. Metoda szacowania wpływu korozji na nośność konstrukcji stalowych mostów drogowych. Zalecenia GDDKiA. Wydawnictwo IBDiM, Żmigród, 2003.

[6] Wysokowski A. Trwałość mostów stalowych w funkcji zjawisk zmęczeniowych i korozyjnych. Praca habilitacyjna. Wydawnictwo IBDiM, Warszawa, 2001.

[7] Chwastek A., Ulewicz M., Problem występowania korozji stalowych drogowych konstrukcji mostowych, [w] Wybrane interdyscyplinarne zagadnienia budownictwa pod red. Nagórski R., Oficyna Wydawnicza Politechniki Warszawskiej, Warszawa 2015, 259-273.

[8] PN-EN ISO 12944-2:2001: Farby i lakiery - Ochrona przed korozją konstrukcji stalowych za pomocą ochronnych systemów malarskich - Część 2: Klasyfikacja środowisk.

[9] Baraniak A., Nowowiejski K. Jak prawidłowo zaprojektować konstrukcję stalową i system jej ochrony przed korozją. Inżynieria Powierzchni, 1/2007, 15-21.

[10] Ustawa z dnia 21 marca 1985 r. o drogach publicznych (Dz.U. z 2015 poz. 460). 


\section{ANALYSIS OF STABILITY OF STEEL BRIDGE OF DEPENDING ON THE CORROSIVE ENVIRONMENT}

\section{S u m m a r y}

The article presents the current statistics on road network Silesian province managed by the Province Road Authority. Shows the amount of the structure depending on the type of the bearing structure. Presents problems concerning the durability of steel bridges taking into account the corrosion current in Poland. Characterizes basic factors affecting the corrosion rate relevant for the assessment of the impact of corrosion on the durability of steel road bridges, among others, weather conditions and factors concerning facility maintenance. Particular attention is paid to the categories of corrosivity of the environment in which they are constructed steel structures, which have a very large impact on the progress and rate of the corrosion process. Procedure to study the effect of corrosion on the durability of the steel bridge structures developed by the Research Institute of Roads and Bridges. Presents a method for calculating the uptime of the structure. Characterized needed to carry out the calculation procedure, reduction coefficients of durability. Based on its analysis of the specified lifetime of the selected design. The calculation is four real bridges with steel girders, which are the supporting structure for the reinforced concrete plate bridge. Selected bridges were built in different areas of the country, characterized by different aggressiveness of the environment - the environment coastal, mountain, urban and neutral. Objects differ in the type of corrosion occurring on the bearing system. Bridges also differ in the age of objects, which has a significant impact on their safety. At the end of the analyzed results obtained from the analysis.

Keywords: steel bridges, durability of bridge structures, corrosion

Przestano do redakcji: $22.12 .2016 r$.

Przyjęto do druku: 31.03.2017 r. 